\title{
Отглавного редактора
}

Восьмой год экономического роста в Российской Федерации демонстрирует новые любопытные нюансы как в макроэкономическом, так и в пространственном аспектах. Для экономических и финансовых властей наиболее заметным и неприятным нюансом стал всплеск инфляции как на потребительском рынке, так и в области издержек производства. Конечно, подобное развитие событий не является внезапным откровением, а наоборот, было вполне предсказуемо на фоне длительного роста мировых цен на энергоносители и увеличения номинальных доходов населения. Кредитная пирамида, которая ориентировалась на высокие инфляционные ожидания, стала дополнительным фактором, толкающим инфляцию вверх. Гораздо более удивительным является то, что неизбежная инфляционная волна не встретила сопротивление со стороны предложения товаров и услуг. Именно отсутствие адекватного роста предложения во многом стало питательной средой инфляции.

Чрезвычайно досадным нюансом макроэкономической ситуации стал рост импорта на фоне ревальвации рубля и дефицита предложения. Изменение пропорций в текущих статьях платежного баланса является тревожным индикатором в рамках среднесрочной перспективы.

Еще одним не менее тревожным нюансом является прогрессирующее увеличение корпоративного внешнего долга, который также подпитывается высокими ценами на энергоносители, ревальвацией рубля и инфляционными ожиданиями.

Таким образом, похоже, что к настоящему времени возник если и не угрожающий, то весьма неприятный макроэкономический контур обратной связи. Это, как известно, характеризуется как ситуация формирования экономической пирамиды. Недавнее событие на мировых рынках - снижение нефтяных цен, а также расширяющиеся волны мирового финансового кризиса, спровоцированные ипотечным кризисом в США, со всей очевидностью показывают пределы развития «пирамидальных» процессов в российской экономике.

Проявились и некоторые нюансы в пространственном аспекте. Пожалуй, самым неприятным из них стала очевидная несогласованность стратегий развития субъектов РФ и национальной экономической стратегии. К настоящему времени более чем треть субъектов РФ разработали и легитимизировали через обсуждение в Минрегионразвития свои стратегии. Однако совершенно непонятно, что далее делать с этими стратегиями. Очевидно, что они не поддаются ни горизонтальному, ни вертикальному согласованию. А это означает, что Россия так же далека от эффективного управления в пространственном экономическом развитии, как и в 90-е гг. прошлого века. Различие заключается в том, что если 10-15 лет назад не было даже надежды на подобное управление, то сейчас существуют большие ожидания в этой области, то есть ситуация тоже очень напоминает инфляцию - инфляцию институциональную. 